Bartosz Sałaj, Ksiądz Adolf Hytrek (1853-1899), zapomniany badacz wczesnego chrześcijaństwa (komunikat), [w:] Starożytność chrześcijańska. Materiały zebrane, red. Józef Cezary Kałużny, t. 4, Kraków 2016, s. 211-221.

DOI: http://dx.doi.org/10.15633/9788374385282.12

Bartosz Sałaj

\title{
Ksiądz Adolf Hytrek (1853-1899), zapomniany badacz wczesnego chrześcijaństwa (komunikat)
}

Adolf Hytrek przyszedł na świat 17 czerwca 1853 roku w małej wiosce Obrowiec w powiecie strzeleckim (dziś powiat krapkowicki) niedaleko Strzelec Opolskich ${ }^{1}$. Jego rodzinna miejscowość należała wówczas do parafii Jasiona. Pochodził z rodziny chłopskiej i był drugim dzieckiem, ale pierwszym synem miejscowego gospodarza Piotra Hytrka i jego małżonki Zuzanny z domu Loss. Dwa dni po narodzinach (19 czerwca 1853) w kościele parafialnym pod wezwaniem św. Marii Magdaleny otrzymał sakrament chrztu świętego. Jego rodzicami chrzestnymi byli: Ignacy Barton i Marianna Modler. Piotr Hytrek trudnił się rolnictwem, aby utrzymać 10-osobową rodzinę. Adolf miał cztery siostry: Małgorzatę (ur. 1852), Joannę (ur. 1855), Marię (ur. 1857), Konstantynę (ur. 1859), i trzech braci: Piotra (ur. 1860) oraz bliźniaków - Pawła i Antoniego (ur. 1863). O matce nie wiemy zbyt wiele. $\mathrm{Na}$ pewno była spokrewniona $\mathrm{z}$ ks. Wiktorem Lossem², zmarła przed-

${ }_{1}$ Do tej pory, poza obowiązkowymi hasłami encyklopedycznymi, powstało zaledwie kilka opracowań dotyczących życia i działalności ks. Adolfa Hytrka: J. Pośpiech, Adolf Hytrek (1853-1899), „Kwartalnik Opolski” 4 (1973), s. 105-109; A. Kiełbasa, Nieznane fakty z życia i działalności księdza Adolfa Hytrka (1853-1899), [w:] Ludzie Kościoła katolickiego na Ziemi Śląskiej, red. K. Matwijowski, Wrocław 1994, s. 115-150; tenże, Ksiadz Adolf Hytrek 1853-1899. Dziennikarz-Ludoznawca-Archeolog, Trzebnica 1996; tenże, Ksiądz Adolf Hytrek (1853-1899) archeolog z kręu G. de Rossiego, „Vox Patrum” 17 (1997) z. 32/33, s. 399-417; J. Pixa, Ksiadz Adolf Hytrek - życie i dzieło, Opole 2009.

2 Ks. Wiktor Loss (1855-1932) - śląski kapłan, publicysta „Katolika”, redaktor „Kuriera Górnośląskiego”, członek Towarzystwa Literacko-Słowiańskiego, Towarzystwa Górno- 
wcześnie, ale gdy Adolf był małym chłopcem, zabrała go na pielgrzymkę do sanktuarium na Górze Świętej Anny w dniu 15 sierpnia, w uroczystość Wniebowzięcia Najświętszej Maryi Panny. Tam ponoć ofiarowała chłopca na służbę Bogu w kapłaństwie ${ }^{3}$.

Pierwsze kroki w edukacji mały Adolf zaczął stawiać w wieku sześciu lat na poziomie elementarnym4 ${ }^{4}$. Podążając za radą miejscowego proboszcza, Hytrek, mając 11 lat (rok 1864), stał się uczniem Królewskiego Katolickiego Gimnazjum w Opolu. Przebywał tam 16 miesięcy, głównie szlifując język niemiecki. Następnie, zdobywszy bardzo dobre świadectwo, został przyjęty do biskupiego Seminarium św. Macieja dla chłopców mieszczącego się we Wrocławiu5. W roku 1873 Adolf Hytrek zdał maturę i jako jeden z pięciu uczniów swojej klasy zdecydował się na rozpoczęcie studiów teologicznych ${ }^{6}$.

Kontynuując edukację na Wydziale Teologicznym Akademii Leopolidańskiej, Adolf Hytrek 8 listopada 1873 roku podczas uroczystej immatrykulacji został włączony w poczet studentów?. Szczególnie interesowała go sztuka starożytna, archeologia chrześcijańska i historia sztuki ${ }^{8}$ Z okresu studiów

śląskiego i twórca biblioteki towarzystwa, działacz społeczny, propagator edukacji w języku polskim; por. M. Pater, Loss Wiktor, [w:] Słownik biograficzny katolickiego duchowieństwa śląskiego w XIX $i$ XX wieku, red. M. Pater, Katowice 1996, s. 244-245.

3 A. Kiełbasa, Nieznane fakty z życia..., dz. cyt., s. 115.

4 J. Pośpiech, Adolf Hytrek..., dz. cyt., s. 143. Został wysłany przed rodziców do swojego krewnego, wiejskiego nauczyciela Büchsa, który potrafił zachęcić chłopca do nauki, a także wpoił mu zamiłowanie do języka polskiego.

5 Tamże. Szkoła miała profil humanistyczny z nauką języka łacińskiego i greckiego. Program edukacyjny obliczony był na dziewięć lat. Hytrek naukę rozpoczął od klasy trzeciej. Wysoki poziom w zdobywaniu wiedzy oraz wychowanie właściwe moralnie i patriotycznie gwarantował dyrektor gimnazjum dr August Wissowa. Po jego śmierci funkcję dyrektora przejął dr Antoni Józef Reisacker, który w trakcie 14-letniej pracy przeprowadził bez większych strat placówkę przez okres walki między państwem a Kościołem.

6 A. Kiełbasa, Ksiądz Adolf Hytrek 1853-1899..., dz. cyt., s. 20.

7 Tamże, s. 29. Ksiądz Kiełbasa przekazuje, że jedyna adnotacja, jaka pojawiła się przy nazwisku Hytrka, informuje o jego nieznajomości języka hebrajskiego.

${ }^{8}$ W. Pawłowicz, Ksiegozbiory polskiego duchowieństwa katolickiego na Górnym Ślasku w XIX $i$ XX wieku (do 1939 r.), Katowice 2009, s. 53. Zgodnie z europejskim nurtem także i we wrocławskiej wszechnicy od połowy xıx wieku wzrosło zainteresowanie antykiem chrześcijańskim. Szczególnie historia Kościoła i patrologia przeżywały rozkwit. Być może pod wpływem wykładów ks. dziekana Hugona Laemmera (kierownik Katedry Teologii Dogmatycznej w latach 1864-1882, pracownik Katedry Historii Kościoła w latach 1896-1897) Adolf Hytrek zainteresował się starożytnością, ale o tym źródła nie mówią. Por. A. Młotek, Teologia katolicka na Uniwersytecie Wrocławskim ze szczególnym uwzględnieniem teologii moralnej, Wrocław 1998, s. 117-120. 
niewyjaśniona zostaje kwestia rzekomej przynależności Adolfa do niemieckiej organizacji studenckiej Winfrida ${ }^{9}$. Rozpoczęte studia po dwóch latach musiały zostać przerwane, było to spowodowane ciągle trwającym Kultur$k a m p f e m^{10}$. Adolf Hytrek został wcielony do wojska wiosną 1875 roku. Służąc w 53 Pułku Piechoty Pruskiej, z czasem zyskał dobrą opinię przełożonych, którzy powierzali mu coraz to bardziej odpowiedzialne zadania. Służba w wojsku trwała pełny rok. Hytrek chciał kontynuować naukę, ale kilka dni przed opuszczeniem koszar władze zlikwidowały Wydział Teologiczny, a na studia w innym miejscu nie było go stać. Na liście studentów figurował do lutego 1877 roku, po czym został skreślony. Oficjalny powód mówił o nieobecności na wykładach, ale nie można wykluczyć interwencji policji, która uważnie przyglądała się zaangażowaniu studenta w polskie sprawy ${ }^{11}$.

We wrześniu 1876 roku pozostający bez środków do życia Hytrek, w porozumieniu z przebywającymi w więzieniu pruskim Karolem i Pawłem Miarkami, objął stanowisko redaktora naczelnego pisma „Katolik”. Krótki okres kierownictwa Hytrka uważany jest za bardzo pomyślny. Nowy redaktor zaostrzył polemikę polityczną, rozbudował rubrykę wiadomości z prowincji, a także postarał się o bieżące informacje regionalne i różne praktyczne porady. Działania te przysporzyły pismu wielu nowych czytelników i prenumeratorów. W tym samym czasie Hytrek współredagował także inne czasopismo Karola Miarki - „Monikę”12.

Dziedziną szczególnego zainteresowania Adolfa Hytrka była folklorystyka. Zaczął od gromadzenia tekstów pieśni ludowych, których na przestrzeni lat uzbierał około tysiąca. Oczywiście dobrą formą popularyzowania swojego zainteresowania był okres redagowania czasopism. W specjalnej odezwie apelował do Górnoślązaków o spisywanie zasłyszanych przy różnych

9 E. Szramek, Ks. Norbert Bonczyk - Homer Górnoślaski i poeta walki kulturnej, „Roczniki Towarzystwa Przyjaciół Nauk na Śląsku” 2 (1930), s. 3. Jednak nazwisko Hytrka nie figuruje w spisie członków, a informację o jego działalności w stowarzyszeniu zostawił nam ks. Emil Szramek, być może posiłkując się faktem wygłoszenia przez studenta teologii referatu na temat przedstawień ukrzyżowania, o czym także wspomina ks. Antoni Kiełbasa.

${ }^{10}$ J. Mandziuk, Hytrek Adolf, [w:] Słownik polskich teologów katolickich, t. 2, red. H. E. Wyczawski, Warszawa 1982, s. 84 .

${ }^{11}$ A. Kiełbasa, Nieznane fakty z życia..., dz. cyt., s. 122. Hytrek zainteresowanie organów bezpieczeństwa zaczął wzbudzać szczególnie od 1870 roku, kiedy to rozpoczął współpracę z czasopismem „Katolik” i jego redaktorem naczelnym Karolem Miarką; por. J. Mandziuk, Historia Kościoła katolickiego na Śląsku, t. 3, cz. 2, Warszawa 2008, s. 365.

${ }_{12}$ J. Pośpiech, Adolf Hytrek..., dz. cyt., s. 105; por. J. Pixa, Ksiądz Adolf Hytrek..., dz. cyt., s. 7 . 
okazjach pieśni i piosenek ludowych, a czytelnicy nie zawiedli. Zapowiadał i zrealizował specjalną publikację zebranych dzieł w rozprawie ludoznawczej $^{13}$. Inicjatywa Hytrka na pewno stałaby się jedną z najefektowniejszych akcji folklorystycznych Śląska, gdyby nie konflikty z prawem i w rezultacie odejście $\mathrm{z}$ redakcji ${ }^{14}$.

Przebywając więzieniu, Hytrek ostatecznie przekonał się o słuszności proponowanej przez siebie na łamach „Katolika” manifestacji wyznaniowej i narodowej Ślązaków, których zapraszał na pielgrzymkę do Włoch, do miejsc ważnych dla Polaków. Rozpoczęła się ona w maju 1877 roku pod przewodnictwem 24-letniego wówczas Adolfa Hytrka. Wzięło w niej udział 106 uczestników - polskich Ślązaków w tradycyjnych strojach swojego regionu ${ }^{15}$. Opis pielgrzymki zamieszczony został w kolejnych numerach „Katolika"16.

Pielgrzymka do Włoch ponownie rozbudziła w redaktorze młodzieńcze pragnienia o kapłaństwie. Nie było to jednak łatwe. Hytrek po powrocie na Śląsk był zagrożony czteromiesięcznym więzieniem i musiał uciekać. Udał się do Krakowa, lecz i tu pomimo licznych seminariów, jako osoby prawie ściganej, nikt nie chciał go przyjąć. Koniecznością stało się dla niego objęcie posady guwernera u hrabiów Potockich w Krzeszowicach. Dzięki życzliwości swoich gospodarzy odbył również podróż do Belgii ${ }^{17}$.

Z pomocą na drodze ku kapłaństwu przyszedł Hytrkowi ks. Stanisław Radziejowski - kolega z dziennikarskich czasów „Katolika”. Poradził mu, aby udał się bezpośrednio do ordynariusza swojej diecezji, bp. Henryka Förstera, przebywającego wówczas na wypoczynku w rezydencji biskupów wrocławskich koło Jawornika. Biskup przyjął kandydata do kapłaństwa i obiecał pomoc. Gdy nie udało się umieścić Hytrka w seminarium w Widnawie,

${ }^{13}$ J. Pośpiech, Adolf Hytrek..., dz. cyt., s. 106-107. Tytuł dzieła to Górny Śląsk pod względem obyczajów, języka i usposobienia ludności, „Przegląd Polski” (1879) z. 3, s. 291-319; z. 4, s. $45-49$.

${ }^{14}$ J. Pośpiech, Adolf Hytrek..., dz. cyt., s. 107. Pierwszy raz Hytrek został skazany na karę grzywny w styczniu 1877 roku. Wyrok spowodował również wspomniane wyżej skreślenie z listy studentów Wydziału Teologicznego. Kolejny proces i wyrok odbywany w więzieniu to marzec 1877 roku. Por. A. Kiełbasa, Nieznane fakty z życia..., dz. cyt., s. 123.

${ }^{15}$ J. Pośpiech, Adolf Hytrek..., dz. cyt., s. 123-124.

${ }^{16}$ Relacje Hytrka drukowane były na łamach „Katolika” nr 21 z 24.05.1877, nr 23 z 7.06.1877, $\mathrm{nr} 24$ Z 14.06.1877, nr 25 Z 21.06.1877. Nie są wyłącznie suchą relacją z miejsc odwiedzanych, ale skrzętnie odnotowują każdy przejaw polskości pojawiający się w trakcie podróży.

${ }_{17}$ A. Kiełbasa, Ksiądz Adolf Hytrek 1853-1899..., dz. cyt., s. 44. Ksiądz Antoni Kiełbasa informuje, że nie udało się ustalić, kto i w jaki sposób pomógł Hytrkowi przedostać się z Krakowa do Krzeszowic. 
bp Förster polecił udać się do Rzymu oraz przydzielił mu odpowiednie stypendium $^{18}$.

W Wiecznym Mieście, do którego przybył już jesienią 1877 roku, Hytrek starał się o przyjęcie do seminarium misyjnego Kongregacji Rozkrzewiania Wiary. Gdy to się nie udało, próbował dostać się do Kolegium Amerykańskiego oraz Amerykańskiego Seminarium Misyjnego w Lowanium (Belgia), ale i tam nie mógł przygotowywać się do kapłaństwa, ponieważ, jak pisze ks. Antoni Kiełbasa, seminarium to kształciło głównie Belgów, Holendrów, Francuzów, Niemców i Irlandczyków, którzy po święceniach mieli podjąć pracę w USA. Pojawiła się szansa, aby Hytrek na czas kończenia studiów aż do przyjęcia święceń zamieszkał w Kolegium Polskim, ale i ta opcja nie została zrealizowana ${ }^{19}$. Ostatecznie Hytrek znalazł schronienie w Kolegium Niemieckim Campo Santo Teutonico, które znajduje się na terenie Watykanu. Przyjął go tam rektor, ks. dr Antoni de Waal. Hytrek mógł mieszkać w kolegium pod warunkiem, że do jesieni 1878 roku ukończy teologię i przyjmie święcenia prezbiteratu ${ }^{20}$.

W Wielką Sobotę, która w roku 1878 przypadała 20 kwietnia, Adolf Hytrek przyjął tonsurę i został włączony do duchowieństwa. 19 maja przyjął cztery święcenia niższe (akolity, lektora, ostiariusza i egzorcysty). Po zdaniu egzaminów i uzupełnieniu wymaganych dokumentów, 25 lipca Hytrek przyjął subdiakonat, a 4 sierpnia święcenia diakonatu. Data święceń prezbiteratu została wyznaczona na 15 sierpnia 1878 roku. Diakon Hytrek został wysłany przez ks. de Waala do domu księży misjonarzy św. Wincentego a Paulo na Monte Citorio, aby duchowo i pastoralnie przygotował się do przyjęcia sakramentu kapłaństwa. W uroczystość Wniebowzięcia Najświętszej Maryi Panny w kościele Matki Bożej na Campo Santo bp Jordan Ballsieper udzielił diakonowi Adolfowi Hytrkowi święceń kapłańskich. Mszę świętą prymicyjną neoprezbiter sprawował 18 sierpnia (rocznica śmierci matki), a wieczorem został przyjęty na prywatnej audiencji u papieża Leona XIII. O wszystkim był poinformowany bp Förster, który wyraził zgodę na pobyt

${ }^{18}$ Tamże, s. 45. Por. J. Pixa, Ksiądz Adolf Hytrek..., dz. cyt., s. 8. Niestety nie wiemy, dlaczego Hytrek nie mógł podjąć nauki w seminarium w Widnawie.

19 A. Kiełbasa, Ksiadz Adolf Hytrek 1853-1899..., dz. cyt., s. 45.

${ }^{20}$ W. Pawłowicz, Księgozbiory polskiego duchowieństwa..., dz. cyt., s. 54. Adolf Hytrek ze względu na brak święceń był wyróżniającą się postacią wśród mieszkańców kolegium księży-studentów z krajów języka niemieckiego, prześladowanych przez Kulturkampf. Ksiądz de Waal zgodził się przyjąć Hytrka, ponieważ ten zrobił na nim wyjątkowo dobre wrażenie. Por. A. Kiełbasa, Ksiądz Adolf Hytrek 1853-1899..., dz. cyt., s. 51-52. 
ks. Hytrka w Rzymie i podjęcie dalszych studiów z zakresu archeologii chrześcijańskiej ${ }^{21}$.

W Kolegium Campo Santo zostały stworzone wręcz idealne warunki do studiowania historii i archeologii. Szczególnie dbał o to ks. dr Antoni de Waal, pasjonat obu dziedzin. Jednym z jego pomysłów była tzw. „Sabbatina" - sobotnie wieczorne spotkania, podczas których jeden z domowników lub zaproszony gość wygłaszał referat naukowy. Ksiądz Adolf Hytrek swoje wystąpienie miał 21 października 1878 roku. W tym samym roku, staraniem rektora kolegium, zaczęto organizować muzeum archeologiczne. Ksiądz de Waal dzięki darowiznom i nabywaniu cennych przedmiotów pomagał studentom archeologii. Troska rektora o studentów w przypadku ks. Hytrka zaowocowała dwuletnimi studiami u boku twórcy archeologii chrześcijańskiej jako odrębnej nauki - Giovanniego Battisty de Rossiego. Ten ułatwił ks. Hytrkowi dostęp do literatury i badań oraz motywował go do nowych poszukiwańn ${ }^{22}$.

Jak wielką szansą dla ks. Hytrka była praca z de Rossim, świadczy dorobek naukowy rzymskiego mistrza. Będąc uczniem innego słynnego archeologa, jezuity Marchiego, szybko doszedł do wniosku, że by stać się wybitnym archeologiem, trzeba połączyć erudycyjną wiedzę teoretyczną z umiejętnościami poszukiwacza-odkrywcy. Odbyte przez de Rossiego liczne podróże po Europie miały na celu pogłębić wiedzę badacza zarówno w zakresie teorii (kwerendy biblioteczne), jak i praktyki (zabytki w muzeach i poza nimi) ${ }^{23}$.

Ksiądz Adolf Hytrek podczas prac z wybitnym naukowcem w rzymskich katakumbach zajmował się chrześcijaństwem trzech pierwszych wieków. O dobrym wpływie, jaki miały na niego studia u de Rossiego, świadczy fakt, że wielu gości Campo Santo chciało, aby polski kapłan oprowadzał ich

${ }^{21}$ A. Kiełbasa, Ksiądz Adolf Hytrek 1853-1899..., dz. cyt., s. 52-54.

${ }^{22}$ A. Kiełbasa, Ksiądz Adolf Hytrek (1853-1899) archeolog..., s. 404. Dotyczyło ono wszystkich prawd wiary zawartych $\mathrm{w}$ apostolskim wyznaniu wiary, które można potwierdzić zachowanymi przedstawieniami w rzymskich katakumbach, a także innych pomnikach z okresu wczesnego chrześcijaństwa. Por. A. Kiełbasa, Ksiądz Adolf Hytrek 1853-1899..., s. 61n; tenże, Ksiądz Adolf Hytrek (1853-1899) archeolog..., dz cyt., s. 404.

${ }^{23}$ T. Górski, Z dziejów archeologii chrześcijańskiej, „Vox Patrum” 11-12 (1991-1992) z. 20-23, s. 177-182. Giovanni de Rossi jest szczególnie znany jako badacz rzymskich katakumb. Przystępując do badań, korzystał z dorobku swojego mistrza, w zakresie historyczno-filozoficznej analizy wielkiej ilości źródeł pisanych, którym zawsze poświęcał mnóstwo czasu i uwagi, wykorzystując swą rozległą wiedzę i doświadczenie. Twórczość naukową de Rossiego określa się na ok. 200 artykułów i publikacji. Warto wspomnieć, że oprócz ks. Hytrka ze szkoły de Rossiego wyszli również dwaj wybitni polscy badacze: ks. Józef Wilpert i ks. Józef Bilczewski (późniejszy arcybiskup Lwowa). 
po wiecznym mieście, ze szczególnym uwzględnieniem miejsc starożytnych i Watykanu. Ksiądz Hytrek w celach naukowych udawał się również poza Rzym. Na początku lat 8o. xIX wieku udał się do Neapolu, aby zapoznać się z wykopaliskami z Pompei. Stał się również jednym z założycieli inspirowanego przez ks. de Waala Collegium Cultorum Martyrum z siedzibą w Kolegium Niemieckim Campo Santo, którego celem było propagowanie kultu męczenników chrześcijańskich ${ }^{24}$.

W marcu 1880 roku ks. Hytrek został zaproszony przez poznanych w Rzymie Fryderyka i Jerzego von Strachwitzów do odbycia podróży do Afryki w charakterze eksperta. Zobowiązali się oni również do pokrycia kosztów wyjazdu. Gdy o owej propozycji dowiedział się prof. de Rossi, zaproponował ks. Adolfowi współpracę przy badaniach i przygotowywaniu publikacji o początkach chrześcijaństwa w Afryce pt. Africa sacra. Przed młodym badaczem zarysowała się realna szansa na wejście w świat uczonych. Po dopełnieniu wszelkich formalności i uzyskaniu zgody swojego biskupa ordynariusza, a także uzyskaniu dodatkowych środków materialnych ks. Hytrek wraz ze swoimi darczyńcami wyruszyli w drogę. 11 kwietnia wpłynęli do Zatoki Tunezyjskiej. W opinii ks. de Waala wyniki badań, które miał przeprowadzić ks. Hytrek, mogły stanowić ważny apologetyczny oręż wobec ataków na Kościół zwłaszcza ze strony protestantów ${ }^{25}$.

Główne badania archeologiczne ks. Hytrek prowadził w Thebessie, która leży w południowej Numidii i nazywana była chrześcijańskimi Pompejami ze względu na bogactwa, które kryje w ziemi. Wspólnie z proboszczem misyjnym ks. Delapardem w odległości $3 \mathrm{~km}$ od Thebessy odkopali stare chrześcijańskie cemeterium z oratorium. W odległości $24 \mathrm{~km}$ od Thebessy ks. Hytrek odnalazł oratorium z vi wieku. Odkrył również nieznane fragmenty łuku triumfalnego, kapitele ze starej bazyliki i płyty nagrobne z chrześcijańską symboliką pochodzące z vi wieku. Wszystkie znalezione przedmioty ks. Hytrek starał się szczegółowo opisaće ${ }^{26}$. W Tunezji, $50 \mathrm{~km}$ od granicy z Algierem, w wąwozie szczepu Nemeucha archeolog odnalazł epitafium z napisem „martyr Dei consultus”, z którego uczynił wierną kopię dla de Rossiego. Odnalazł także inny fragment płyty z napisem: „Aream et sepulcra cultor. Verbi contulit [...]”. Będąc w Announah i Thagaste,

\footnotetext{
${ }^{24}$ A. Kiełbasa, Ksiądz Adolf Hytrek (1853-1899) archeolog..., dz. cyt., s. 404-405.

${ }_{25}$ Tenże, Ksiądz Adolf Hytrek 1853-1899..., dz. cyt., s. 73; tenże, Nieznane fakty z życia..., dz. cyt., s. 134 .

${ }^{26}$ Tenże, Ksiądz Adolf Hytrek (1853-1899) archeolog..., dz. cyt., s. 408.
} 
naszkicował wiele zabytków, a zwiedzając Orleansvike i Cherchel, doszedł do wniosku, że znajdujące się tam napisy na chrześcijańskich epitafiach nagrobnych dają nowe możliwości w zrozumieniu relacji cesarstwo-Kościół, począwszy od Septymiusza Sewera do Konstantyna Wielkiego ${ }^{27}$. Z badań afrykańskich ks. Hytrek przywiózł wiele eksponatów. Chyba najbardziej znane, ale i zasługujące na szczególną uwagę są wczesnochrześcijańskie lampy. $\mathrm{O}$ archeologicznych dokonaniach ks. Hytrka w Afryce można przeczytać w „Biuletynie Archeologii Chrześcijańskiej” wydawanym w Rzymie ${ }^{28}$.

Ksiądz de Waal chciał ponownie wysłać zdolnego archeologa do Afryki, aby mógł kontynuować niedokończone badania, jednak nie udało się zorganizować niezbędnego wsparcia finansowego ${ }^{29}$. Powoli również dobiegał końca okres rzymski w życiu ks. Hytrka. Mimo chęci podjęcia pracy duszpasterskiej w rodzinnym kraju nie mógł wrócić na Śląsk. W międzyczasie pojawiła się możliwość objęcia przez niego dobrego stanowiska duchownego w Belgii ${ }^{30}$, jednak ostatecznie decyzją swojego ordynariusza ks. Adolf Hytrek został mianowany kapelanem domowym sióstr św. Marii Magdaleny od Pokuty w St. Josefberg koło Zagrzebia w Chorwacji ${ }^{31}$.

Poza stanowiskiem kapelana ks. Hytrek przyjął również obowiązki niedzielnego i świątecznego kaznodziei w domu generalnym sióstr miłosierdzia $^{32}$. Jednocześnie nie stracił kontaktu ze środowiskiem naukowym. Jako ceniony archeolog, dobrze pamiętany z czasów pracy w rzymskich katakumbach św. Kaliksta, miał dobre stosunki z miejscowym uniwersytetem. Często był zapraszany na seminaria naukowe, gdzie prowadził wykłady. Z czasem został również ekspertem rządu węgierskiego w dziedzinie archeologii, a także członkiem Towarzystwa Historycznego w Styrii, co znacznie ułatwiało mu prywatne badania archeologiczne na tych terenach, których niestety jedynym odnotowanym echem był przedłożony na I Międzynarodowym Kongresie Archeologii Chrześcijańskiej w Splicie referat pt. Starokršćansko grobište sv. Sinerota u Sriemu ${ }^{33}$. Oczywiście utrzymywał stały kontakt

${ }^{27}$ Tenże, Ksiadz Adolf Hytrek 1853-1899..., dz. cyt., s. 79-8o.

${ }^{28}$ J. Pixa, Ksiadz Adolf Hytrek..., dz. cyt., s. 12.

${ }^{29}$ A. Kiełbasa, Ksiadz Adolf Hytrek 1853-1899..., dz. cyt., s. 86.

${ }^{30}$ Tenże, Ksiądz Adolf Hytrek (1853-1899) archeolog..., dz. cyt., s. 411.

${ }^{31}$ J. Mandziuk, Historia Kościoła katolickiego..., dz. cyt., s. 510. Zakonnice musiały opuścić swój dotychczasowy klasztor w Czarnowąsach. Por. W. Pawłowicz, Księgozbiory polskiego duchowieństwa..., dz. cyt., s. 54.

${ }^{32}$ J. Pixa, Ksiądz Adolf Hytrek..., dz. cyt., s. 8.

${ }^{33}$ A. Hytrek, Starokršćansko grobište sv. Sinerota u Sriemu, [w:] Acta Primi Congressus Internationalis Archaeologiae Cristianae, ed. E. Marin, V. Saxer, Citta del Vaticano-Split 1993, s. 17-23. 
z profesorami i przyjaciółmi w Rzymie, w tym także z poznanym w 1885 roku podczas Wielkanocy w Campo Santo Teutonico ks. Józefem Wilpertem. Z chorwackiego okresu życia ks. Adolfa Hytrka ważny jest również pobyt w nowym, podominikańskim klasztorze sióstr magdalenek w Studenicach na terenie Słowenii ${ }^{34}$. Zafascynowany archeologią i historią miejsca ks. Hytrek zaczął gromadzić i opracowywać dokumentację kościoła ${ }^{35}$. Jak pisze sam autor: „żywe zainteresowanie przeszłością starego konwentu dominikanek w Studenicach, jednym z najpiękniejszych miejsc południowej marchii Styrii oraz osobą jej założycielki Zofii (Sophie) von Rohatsch było mi bardzo bliskie" ${ }^{36}$. Wiadome jest na pewno, że polski kapłan-archeolog wziął udział w wyżej wymienionym kongresie archeologicznym, który odbył się w dniach 20-22 sierpnia 1894 roku w Splicie ${ }^{37}$.

Po 15 latach pracy kapelan Adolf Hytrek wreszcie mógł powrócić na Śląsk ${ }^{38}$. Ksiądz Hytrek w rodzinne strony wrócił na początku 1896 roku. W dużej mierze swój powrót zawdzięczał spokrewnionemu z nim ks. Wiktorowi Lossowi, który, ustępując z funkcji redaktora „Gazety Katolickiej”, właśnie ks. Hytrka zaproponował na swoje miejsce. Nowy redaktor naczelny pracował przy wydawaniu gazety do końca tego roku, bo już 14 grudnia 1896 roku decyzją ordynariusza wrocławskiego, kard. Jerzego Koppa,

${ }^{34}$ A. Kiełbasa, Ksiądz Adolf Hytrek (1853-1899) archeolog..., dz. cyt., s. 413. Por. tenże, Ksiądz Adolf Hytrek 1853-1899..., dz. cyt., s. 92-93. Tam księdza kapelana odwiedzał ks. Antoni de Waal.

${ }^{35}$ J. Pixa, Ksiądz Adolf Hytrek..., dz. cyt., s. 11. Wysiłki te przyniosły książkę pt. Sophie von Rohitsch und das Stift und Gotteshaus Studenitz, wydaną kosztem własnym w drukarni św. Cyryla w 1895 roku.

${ }^{36}$ A. Hytrek, Zofia von Rohatsch $i$ konwent oraz dom boży w Studenicach, tłum. A. Küchnemann, J. Pixa, Opole 2013, s. 10.

${ }^{37}$ Oprócz pozycji książkowej i udziału w Kongresie, na którym przybliżył materialne świadectwa kultu świętych męczenników z okresu prześladowań Dioklecjana na przykładzie nekropolii w Sriem, praktycznie nic więcej nie wiemy na temat 15-letniego pobytu ks. Hytrka w Chorwacji. Por. A. Hytrek, Starokršćansko grobište sv. Sinerota u Sriemu, dz. cyt., s. 17-23. Antoni Kiełbasa w zakończeniu swojej książki zauważa, że informacje o ks. Hytrku mogą znajdować się w archiwum diecezji Maribor. Stephan Heid, opracowując działalność naukowa Antona de Walla, sygnalizuje, że mieszkańcy Kolegium niemieckiego, w tym zwłaszcza ks. Hytrek, przyczynili się nie tylko do zorganizowania kongres, ale również badań archeologicznych w Dalmacji: S. Heid, Anton de Waal, Njemački zavod u Rimu i starokršćanska arheologija u Dalmaciji, Kačić-Split 2009-2011. Tezę tę zdaje się potwierdzać Miroslav Jeremic, który opracowując najstarsze badania archeologiczne w Sirmium, podkreśla ogromny wkład Polaka. M. Jeremic, Adolf Hytrek et les premieres fouilles archeologiques a Sirmium, „Starinar” 55 (2005), s. 115-129.

${ }^{38}$ A. Kiełbasa, Ksiądz Adolf Hytrek 1853-1899..., dz. cyt., s. 98. 
został mianowany administratorem parafii Świętych Apostołów Szymona i Judy Tadeusza w Szymiszowie w archiprezbiteracie strzeleckim. Początki duszpasterzowania nowego administratora nie należały do łatwych; do codziennych obowiązków parafialnych dodał działalność etnologiczną i patriotyczną, towarzyszyły mu też ciągłe kłopoty materialne. Od połowy 1899 roku ks. Hytrek zaczął poważnie chorować na serce. Po konsultacjach z lekarzami zdecydował się na sześciotygodniowy urlop zdrowotny, który po uzgodnieniu z przełożonymi odbywał w Marienbadzie (dziś Mariańskie Łaźnie w Czechach) ${ }^{39}$. Już na miejscu jego stan uległ pogorszeniu i zdecydowano o przewiezieniu pacjenta do kliniki we Wrocławiu, gdzie 5 września 1899 roku, w 46 roku życia i 22 roku kapłaństwa, ks. Adolf Hytrek zmarł ${ }^{40}$. Na plebanii w Szymiszowie oprócz rzeczy codziennego użytku i pustej kasy znajdowało się wiele książek ${ }^{41}$. To znalezisko doskonale charakteryzuje zmarłego. Wśród kolekcji ksiąg odnaleziono Biblię, a także dzieła z zakresu teologii ogólnej i moralnej, liturgiki, biblistyki, dzieła papieży i ich omówienia, jak również kanony Soboru Trydenckiego z Indeksem Ksiąg Zakazanych. Jednak większość odnalezionych pozycji zajmują te poruszające kwestie historyczne. Ksiądz Hytrek posiadał sporo dzieł poświęconych dziejom Kościoła pierwszych wieków, a także pedagogice, architekturze, sztuce i epigrafice początków chrześcijaństwa ${ }^{42}$.

Koledzy księża opłacili przewiezienie zwłok zmarłego do Szymiszowa, a także kupili trumnę. Ksiądz Adolf Hytrek został pochowany na miejscowym cmentarzu, gdzie do dziś zachowany jest fragment jego grobu. Wszelkie sprawy pozostałe po zmarłym, takie jak uregulowanie długów czy intencje mszalne, zostały zlecone ks. Teofilowi Schöneichowi, a także na prośbę ojca i siostry zmarłego - ks. prałatowi de Wallowi ${ }^{43} .28$ lutego

${ }^{39}$ Tamże, s. 109. Na czas nieobecności w parafii proboszcz był zastępowany przez ojców franciszkanów z Góry Świętej Anny. Jednak stan zdrowia ks. Hytrka nie poprawiał się.

${ }^{40}$ J. Król, Dzieje parafii Szymiszów, Opole 1995, s. 75. Parafia liczyła wówczas ok. 1300 wiernych, a ks. Hytrek obejmował placówkę po znanym śląskim kapłanie ks. Aleksandrze Skowrońskim. Rozwój parafii był gwarantowany dzięki naturalnemu bogactwu złóż wapiennych. Wzrastała liczba mieszkańców, szczególnie tych wychowanych w tradycji polskiej, działały dwie szkoły, a w parafii prężnie Bractwo Świętej Rodziny i Bractwo Różańcowe.

${ }^{41}$ A. Kiełbasa, Ksiadz Adolf Hytrek 1853-1899..., dz. cyt., s. 109.

${ }^{42}$ W. Pawłowicz, Księgozbiory polskiego duchowieństwa..., dz. cyt., s. 58. Problematyka książek ks. Hytrka ukazuje nam go jako kapłana zorientowanego w aktualnych sprawach Kościoła. Posiadał prace dokumentujące dyskusje wokół dogmatu o nieomylności papieża ustalonego w czasie soboru watykańskiego I, encykliki Quanta cura i Syllabus papieża Piusa Ix. W kolekcji są także książki o tematyce polskiej czy poruszające dzieje Śląska.

${ }^{43}$ A. Kiełbasa, Nieznane fakty $z \dot{z} y c i a . . .$, dz. cyt., s. 148. 
1900 roku w Rzymie w kościele Campo Santo Teutonico, gdzie ks. Hytrek przyjął święcenia prezbiteratu, cała wspólnota Collegium Cultorum Martyrum celebrowała za niego nabożeństwo żałobne ${ }^{44}$.

44 Tenże, Ksiądz Adolf Hytrek 1853-1899..., dz. cyt., s. 110. 